Article

\title{
Family History in an Old Genre: The Strange Tales of Lü Meisun and Guo Zeyun
}

\section{Rania Huntington}

Department of Asian Languages and Cultures, University of Wisconsin, Madison; Madison, WI 53706, USA; huntington@wisc.edu

Received: 17 July 2019; Accepted: 2 September 2019; Published: 23 September 2019

\begin{abstract}
Recording personal and family history has been a secondary purpose of the zhiguai (tales of the strange) genre from its inception. As there is no proven female author of a surviving collection before the 20th century, these family histories were shaped by male collectors recording tales told by both female and male informants. Yet in the Republican period, when the practice of recording strange incidents from memory or hearsay had become a marginal practice, Lü Meisun 呂美荪 (1881-1945) published two collections. Lü's work stands at a fascinating intersection of gender, genre, and cultural change. She presents a family history centered on the female side of her family and her personal spiritual autobiography against the larger backdrop of cultural transformation from the late Qing through the Republican period. In this paper, I consider a male author of zhiguai during the same years, Guo Zeyun 郭則澐 (1882-1946), for comparison. With their differing conceptions of family, both writers strive to convert familial memory and strange experience into meaning relevant for a wider audience in the present moment.
\end{abstract}

Keywords: family; gender; karma; memory; narrative

\section{Introduction}

For most of its history, the strange tale (zhiguai 志怪) is a genre with many female informants but no identified female authors of surviving works (Huntington 2010, p. 35). Yet in the Republican period, when the practice of recording strange incidents from memory or hearsay had become a marginal rather than mainstream practice, Lü Meisun 呂美䔉 (1881-1945) authored two works at least partially in the genre, 11 years apart (see brief discussion in Zhang 2011, p. 355). What difference do her gender and her historical moment make to her tales? She creates a family history from a female perspective, centered on the mother (also discussed in Qin 2010, p. 265); a continuation and transformation of the didactic use of the genre; and a dialogue between the past and the present concerning the meaning of strange experience. Here, I consider a male author of zhiguai during the same years, Guo Zeyun 郭則 澐 (1882-1946), for comparison. Guo was a close contemporary to Lü Meisun, shared her interest in family history, and retold several of her stories in his own collections.

Lü Meisun was the second in a family of prominent literary sisters, so her zhiguai practice can be placed in context of all the sisters' biographies and their works in other genres, most famously the poetry and lyrics of the third sister, Lü Bicheng (Fong 2004; Xu 2015). The case of the Lü sisters and some of the material I discuss here have also been used to construct histories of girlhood and the formation of the cainü 才女 (talented girl) during this transitional historical period (Qin 2010; Qin and Bruce 2018).

Some of the key functions of zhiguai are transmitting a view of the cosmos and preserving individual lay religious experience (Campany 1996; Dudbridge 2002). Both Lü and Guo labor to use the genre to make sense of personal and familial experience in the face of transformation and loss. 
I structure my discussion, first, following the structure of the family and, second, that of larger scale historical change.

\section{Sources}

Neither of Lü's works is presented as zhiguai in title. Yinweishi bilu寅畏室筆錄 (Brush Record from the Chamber of Awed Respect, 1930, Shanghai) is explicitly framed as a didactic work, written to prove the principle of karmic retribution. Printed by a Buddhist publishing house, its printing and distribution are presented as acts of merit both in the paratext and within stories. Mianliyuan suibi葂麗 園隨筆 (Casual Jottings from the Mianli Garden, 1941, Qingdao) is more diverse in content and tone, as typical of suibi, containing notes about her travels and acquaintances as well as strange tales. At the time she writes it, she has just passed the significant age of $60 \mathrm{sui}$, and reflections on her mortality and the legacy she can leave in words are part of her project. In her preface she describes it as mixing in "interesting events worth crying over or singing about" with tales of karmic consequence (Lü 1941a). As will be discussed below, the two books contain a number of overlapping stories with some textual variation but they are arranged entirely differently. In the years between the publication of her own collections, she also edits and publishes a collection of her late father's miscellaneous works, Jingran zhai $z a z h u$ (Miscellaneous Works of the Jingran Study, 1934), which includes a chronological autobiography, providing a different view of family history, his perspective nested within her perspective as editor.

Although she does not label her collections in either title or paratext as zhiguai, all of the stories in Yinweishi bilu and some of the entries in the Suibi have both the formal and thematic traits of the genre: relatively short narratives in Classical Chinese relating experiences related to reincarnation, heavenly reward and punishment, meaningful dreams, or encounters with ghosts or transformed animal spirits, set in historical space and time, often including names of informants who told the story or the situation in which the story was told. Some of the most prominent collections of the Qing share with her books the title form of a study or garden name followed by a generic term for casual prose, though they use biji 筆記 rather than suibi or bilu: for example, Yuewei caotang biji 閲微草堂筆記 and Youtai xianguan biji 筆記. Her reprinting of selections from a 19th century author's collection of tales of retribution, the Quanjielu jieben 勸戒錄節本, in 1933, reveals her consciousness of the tradition of exclusively didactic collections (Xu 2015, p. 11). ${ }^{1}$

One of the significant differences between Lü Meisun's two tale collections is the deliberate anonymity of characters and informants of stories in Yinweishi bilu. Although there is sometimes enough identifying information so that identities could be determined, most people are describes as mou 某 (so and so) and a general noun. Even for her own family members, their relationship to her is given, but their names are not. Concealing identities to avoid public embarrassment for individuals or families does not seem to be the reason, because the same anonymity is used for positive and negative stories, for tellers of stories and their protagonists. Sometimes, she provides enough identifying information that those in smaller circles would have had no difficulty identifying the protagonists of stories: for example, she mentions that one informant's husband was once the principal of the Hehai School of Engineering (Lü 1930, pp. 5-6). Lü Meisun is herself an anonymous author, writing under the pseudonym Yinweishi zhuren 寅畏室主人 (Master of the Chamber of Awed Respect), one reason perhaps the book is sometimes omitted from lists of her collected works. ${ }^{2}$ Anonymity may work to extend the didactic applicability of the stories, making them not merely chance events that happened to a specific person at a specific moment time, but karmic consequences for anyone who did the same actions. It may also aid accessibility. According to her preface, she intends this collection to be comprehensible to anyone who can read, so perhaps she assumes that the details of people's identities

1 For background on Liang Gongchen's 梁恭辰 Quanjie jinlu 勸戒近錄 see Ning (1996), p. 341.

2 It is not discussed in Xu (2015). I base my attribution on the overlap between it and Mianliyuan suibi and Guo Zeyun's attribution in Dongling xiaozhi (Guo [1934] 2010, 7.140). I consulted a copy in the Beijing Capital Library. 
will only add needless confusion. In contrast, the Suibi is aimed at a more cultured audience, who will require identifying details in order to appreciate her recollections of scholars of earlier generations as well as her weird stories.

The reliability of sources is an overt concern for Yinweishi bilu in a way it is not for the Suibi. She frequently stresses that this was something the informant had seen him-/herself, or that the informant was an honest person overall. The karmic tales of Yinweishi bilu are narrated in a predictable order: cause 因,consequence 果, then sometimes with a summary remark. The Suibi's narrative structure can be more varied.

Guo Zeyun compiled three zhiguai collections explicitly identified as such, Dongling xiaozhi 洞 靈小志 (Small Record of the Spirit of the Cave, 1934) and its two sequels Dongling xuzhi 洞靈續志 (Continued Record of the Spirit of the Cave, 1936) and Dongling buzhi 洞靈補志 (Addition to the Record of the Spirit of the Cave, after 1936 but unpublished until 2010), as well as a book devoted to preserving the memories of his paternal family, Jiu de shu wen 舊德述聞 (Relating What I have Heard about Prior Virtue, 1936). ${ }^{3}$ His collections differ stylistically from hers in not giving titles to individual stories. ${ }^{4}$ It is his zhiguai collections, relating tales from other families, that retell Lü Meisun's stories.

\section{Family History: Which Family?}

Zhiguai is a potential vehicle for family history from the very beginnings of the genre, when the fourth century compiler Gan Bao was said to have been motived to collect zhiguai because of the experience of his late father's concubine miraculously surviving being interned in a tomb, apparently tended by her late husband's ghost (Gan and Tao 2004, 2:8.557). ${ }^{5}$ Tales from hearsay are central to the genre, and the first stories most people hear are told in a familial context, by elders to children. Qing zhiguai by male authors already reveal a definition of family broader than the patriline, including stories from mother's family and in-laws. ${ }^{6}$

Lü's mother Yan Shiyu 嚴士瑜 (-1913), deceased at the time of writing, is an essential voice and absolute moral authority in her daughter's two tale collections. She is a source of unquestionable honesty and a commander of the narrative, at one point in tears bidding her daughter write a poem about a cousin who was a Taiping-era martyr (Lü 1941a, p. 97). Her dream experience confronting a sheep (goat) and a pig in the netherworld, who threaten her until she tells them her family does not eat mutton or pork, provides the foundation for the next generation's advocation of vegetarianism. Lü Meisun recalls her mother's reported speech from her dream as much more straightforward than her usual reserved manner (Lü 1930, pp. 21-22; Lü 1941a, p. 88). This suggests that her mother may have three voices in Lü's recollection: the reserved voice of a wife then a widow, the defiant voice in the dream, and the voice instructing her daughters with her own dreams and the experiences of earlier generations. As will be discussed below, her dreams of her daughters' earlier incarnations serve to frame their essential characters and fates.

Even when not explicitly attributed to her mother, Lü's tales are slanted towards maternal relatives. This is explained by family history: after her husband's death, facing paternal relatives seizing their property, Yan Shiyu and her daughters were forced to take refuge with her natal family, so that from the age of 12 on, Lü Meisun had more extended contact with them than with the Lüs. Lü's husband Zhu Hanzhang 朱翰章 and his family seem entirely absent from her stories. ${ }^{7}$

3 See discussion in Zhang (2011), pp. 344-50.

4 The titles in the 2010 edition of Dongling xiaozhi et al. are the addition of the modern editor. In not giving anecdotes titles he is following the practice of Ji Yun and more recently Yu Yue.

5 Gan Bao does not include this tale in Sou shen ji 搜神記 himself, but it is included in the sequel as well as his biography in the Jin shu 晉書.

6 Ji Yun includes stories from both the maternal and paternal sides of his family, while Yu Yue also records story from his father, daughters-in-law, and granddaughter-in-law. See (Huntington 2010, pp. 37-39).

7 On their marriage see (Xu 2015), p. 177. 
The earliest figure of family history included in both books is Lü Meisun's mother's great-grandfather, who leaves a lingering heritage of virtue: not only does a mysterious scent of sandalwood waft in the air at the point of his death, but also, later, whenever one of his sons or grandsons is about to die of old age, the same scent is perceived. This ceases after the generation of his grandchildren, meaning Lü Meisun's maternal grandfather, the halfway point in generations between this virtuous predecessor and herself (Lü 1930, pp. 11-12; Lü 1941a, pp. 48-49). ${ }^{8}$.

Yan Shiyu is also the granddaughter of the prominent woman writer and anthologist Shen Shanbao 沈善寶 (Xu 2015, p. 6). Lü Meisun mentions her in one item in the Suibi, although the entry is titled with Shen's husband's name rather than her own (Lü 1941a, p. 51). The connection is ritual rather than biological: Meisun's mother's mother was the daughter of Shen's husband by an earlier wife. Although Shen's literary talent and fame is noted, it is her submission to a mother-in-law who does not value her talent and her own sternness to her stepchildren, in turn, that win more attention in the narrative. Shen is the only one of Lü's great-grandfather's three successive wives who is not in some way afflicted by ghosts. Although Yan was plainly an educated woman, the continuity Lü celebrates with her mother and her female kin is moral rather than literary.

Even a tale from the male side of Lü's family (from her father's clan, but not close kin) reveals an inclusive vision of the patrilineal family. While this kinsman is serving in Hubei, far from the family's native place, a local servant who can see ghosts describes the appearance of the family members he sees returning to receive offerings at Qingming, including two young women, later identified as the biological sister and adoptive sister of the patriarch, both of who had died before marriage (Lü 1930, p. 25; Lü 1941a, pp. 66-67). Unmarried girls like these, strictly speaking, should not take part in their paternal family's sacrifices but here, not only are they present but also the knowledge of them, which the servant would be even less likely to learn from other sources than main-line male ancestors, provides the confirmation of his vision.

\section{Fate of the Father's Line}

A story representing a turning point in the history of Lü Meisun's paternal family is told near the beginning of both volumes. Her late father Lü Fengqi was deceived by unscrupulous real estate dealers to bury his parents on a site in his hometown of Jingde 施德, Anhui already containing an older tomb. Working at night using the pretext of the summer heat, the workmen dispose of the older corpses. Subsequently the overseer has a near-death experience, in which he is brought to the underworld and confronted by the angry former inhabitant of the tomb. He is allowed to return to the world of the living to warn Lü Fengqi to move the tomb. Since the broker had earlier assured him there was no old tomb there, he assumes they are trying to cheat him by forcing him to pay for the relocation. Moreover, he has to leave for Beijing almost immediately, so he refuses. The workmen and overseer die shortly thereafter. Over the following years span Lü Meisun's father's entire male line (he had been one of six brothers) dies out; both of her brothers die young. In addition of the seven women of her generation she and her three sisters were disinherited, scattered to support themselves, and her three female cousins either died young or were married to poor men (Lü 1930, pp. 3-4; Lü 1941a, pp. 9-10). Karmic consequence has extended beyond the patriline and includes a kind of fate that would have been more rare in earlier generations, women working outside of the family structure as educators and writers to support themselves.

The main events of the story are the same in both versions, but the framing and conclusions are rather different. In the Suibi she relates the circumstances of her hearing the story first, in the Yinweishi bilu after the events of the tale. She learns of these events from before her own birth many years later, in the 1920s, from a man from the same hometown who had gone back to take the local level of the exam right after the deaths of the workmen. It is not a story her father knew in its entirety, and not one 
he chose to tell even about the part he may have known. Even admitting she was apparently not in Jingde at the time, her mother is also uncharacteristically silent. Lü's choice to tell it is also fraught. She closes the Suibi version saying: "In my private opinion, this event was caused by my late father's neglect; because he was too fatigued, he did not have time to investigate carefully. Originally, I did not dare transmit and show it to others. But his error was unintentional and can warn the world. Writing it directly like this and not concealing it for my father's sake, how can I avoid being charged with the crime of unfiliality"? This version does not make explicit what behavior the story warns against. Fatigue and overwork? Damaging old tombs? Being cheated? Not believing the accounts of angry spirits? In the Yinweishi bilu, she makes it clear it is the latter, stating her father had been virtuous all his life but it was regrettable he did not believe in ghosts and gods, and she records this to warn other skeptics.

In her father's chronological autobiography, the burial of his parents figures as a turning point in a fundamentally different way. The family had suffered devastating losses during the Taiping wars, whether as the direct consequences of the violence or the indirect consequence of poverty and starvation. The surviving brothers had each gone their own way to find a path for survival. With his newly won status as a jinshi graduate, Lü Fengqi buried all those within the five degrees of mourning who had been left unburied, including uncles, nieces, and nephews as well as his direct line. At the same time he contributed to the rebuilding of their ancestral temple (Lü Fengqi 1934, pp. 43a-43b). What for him was the consolidation of the family's continuity is in his daughter's retelling its undoing. The tale also suggests tensions between the native son made good who returns to his hometown to claim the land he wants then leaves in haste, and those who must stay behind to live with the consequences.

Guo Zeyun also records this story, but it is rendered anonymous, with Lü's father identified only as from Anhui. The daughter as source is entirely absent. Discussion of the justice of these consequences frames the tale: Guo concludes that Lü Fengqi is not culpable for what happened when he did not know about the former occupants of the grave site, but he is at fault for ignoring the warning when he did know (Guo [1934] 2010, 6.121). Guo read Lü Meisun's collection with attention, and considered some of the same things memorable, proving her right about the potential broader applicability of her tales. His versions reveal the process of transmission as the personal is removed, leaving the didactic core.

\section{Virtuous Women Struggling against Male Doom}

In Yinweishi bilu, the account of the scandal of the burial is framed by two tales of female virtue. The previous story is an account of her great-grandmother (mother's father's mother), who was rewarded for her kindness to a field hand with three additional years of life (Lü 1930, pp. 2-3; Lü 1941a, pp. 18-19). The following story describes her mother dreaming of her father's previous wife Jiang Boluan (Lü's "former mother" 前母) entrusting her biological sons to their stepmother's care. A wife dreaming of her deceased predecessor is an established type, with examples in in both Ji Yun's and Yu Yue's collections. ${ }^{9}$ Although representing a female-centered narrative tradition, with women telling a story emphasizing the connection between them and lack of jealousy or ill will on both sides, by minimizing the disruption of a new woman succeeding to the maternal role, these transactions also serve the interest of the patriarchal order. Yan Shiyu dreams of a woman she had never seen before asking her to take good care of her sons; if she does, the stranger would in turn take good care of Yan's daughter. Her dream receives three levels of external confirmation: she is told the appearance of the woman in the dream is that of her predecessor; the next day her husband arrives from Jiangxi bringing her stepsons, whom she meets for the first time; her daughter, who had been burning up with fever that night, then recovers (Lü 1930, p. 5; Lü 1941a, pp. 26-27). The last confirmation has ambiguous weight: did the deceased wife save her successor's daughter from disease or was she the 
cause ${ }^{10}$ This element of threat does not seem as clearly preserved in male writers' versions of the conversation between the former and present wife. Lü adds a comment that people should learn from these stories to be filial, as mother's care lasts beyond the grave. Fitting the tale into this didactic frame feels slightly forced, because the more important theme is reinforcing the familial memory of the departed woman and the virtue of Lü's mother, who survives to do the daily work of care. ${ }^{11}$ The tale also commemorates a moment of knitting together severed parts of the family. For almost ten years, including after their mother's death, Lü Fengqi's sons had lived apart from him with their maternal relatives, unable to recognize him when he meets them again a year before bringing them to live with his new wife (Lü Fengqi 1934, pp. 34, 42-44).

Lü Meisun follows the story of the burial with a story about her eldest brother's end, the whole of his life passing between two anecdotes. After being robbed on the road, he reports the crime. Either five or seven men, depending on the version, are captured and put to death, but it turns out that that although they were robbers, they were not the ones who had robbed him. Soon afterwards he falls ill and constantly sees these men standing before his sickbed, staring at him accusingly. They stay away when his mother (his stepmother Yan Shiyu) is with him, so she never leaves his side. Nevertheless, he dies in the end (Lü 1930, p. 5; Lü 1941a, p. 58). In both versions, Lü concludes that these ghosts were taking advantage of his weakened condition and were not the cause of his illness. How much more retribution would there be for those who killed others deliberately?

Again, the consequences of error for the men of the family are out of proportion with their intentions, as the logic of the implacable fury of ghosts works under and against the framework of moral retribution. In the Yinweishi bilu the causality of family history is clear: he is a victim of the doom of the paternal line caused by the ill-chosen gravesite. The Suibi includes the detail that he liked to wear extravagant clothes, suggesting he may have attracted the attention of thieves. By staying night and day by her stepson's sickbed to keep the ghosts at bay, Yan Shiyu has kept her promise to her predecessor to the end. Her power to ward the ghosts away is an indirect description of her virtue, but ultimately it is not enough.

Lü includes a more violent version of the women of the family persevering when a male kinsman descends to madness. During the chaos of the Taiping Civil War her maternal grandmother went to Beijing, travelling with her children in the company of a nephew of the same clan. When the nephew assists with the funeral of an acquaintance's son who had killed himself ${ }^{12}$, the bereaved mother gives him a silk robe the deceased used to wear. Soon he, too, descends into madness, sharpening a knife wanting to kill people. Her maternal grandmother is able to prevaricate and hold off the aspiring murderer for an entire night, until he runs off and is not heard from again (Lü 1930, pp. 9-10; Lü 1941a, pp. 53-54). ${ }^{13}$ Details vary between the two versions. In the Suibi, at the same time as voicing murderous intent, he weeps missing his parents, suggesting the traumatic experience of separation in the war as one cause of his madness. Within the story the underlying logic is contamination: wearing clothing owned by someone who had fallen prey to insanity causes insanity, with the cause of the other

10 The baby girl in this story is Lü Meisun's eldest sister Huiru. Lü Meisun also describes a similar story in another family (Lü 1930, p. 9).

11 The story of her younger sister's (because their fourth sister Kunxiu was very young at the time, this is probably Bicheng) vision of her eldest brother's late fiancée, who had died before marriage, is similar. The soul appears silently to the sick young girl who must ask others to identify the apparition. Hearing about it her betrothed is moved. Appearing to her would-be spouse could have implications of an erotic ghost story, but approaching a sick young girl also has elements of threat, imperfectly contained by Lü Meisun's didactic summary that even dead she still cared about her husband's family (Lü 1930, pp. 22-23). The temporal details of this story do not exactly match other records of the eldest brother's first engagement and marriage (Xu 2015, p. 247).

12 In this and an earlier anecdote, the family of Xu Hanlin 徐翰林 presents another case of perishing of the paternal line while female survivors persevere. In the end only one grandson of a different surname survives, due to the efforts of his concubine (and non-biological) grandmother (Lü 1930, p. 9).

13 Guo Zeyun tells a version of the same story with the family not identified (Guo [1934] 2010, 2.34). 
family's son's madness never explained. Although in Yinweishi bilu Lü adds that one should never accept the objects of the dead, let alone seize them, this is a rather forced moral interpretation.

Describing suicide in other families may serve to allude to a story she does not tell. Though she lists it among the consequences of the ill-fated burial of ancestors, Lü Meisun does not assign a motive for her second brother's suicide by hanging, four years before the death of their eldest brother. However, in his chronological autobiography her father says the young man killed himself after being rebuked for 逃學, skipping his studies or avoiding school (Lü Fengqi 1934, p. 49b). He describes himself as sick with grief for several months. In the year of his eldest son's death he stops making entries in his autobiography altogether, leaving Lü Meisun decades later to fill them in and depict a man who never recovers from his grief. The culture has a rich tradition of ghosts as causes of suicide, but the family does not give their loss this narrative form. To write about the improper burial indirectly giving her father responsibility for both sons' deaths is to avoid writing about the more direct responsibility he bears for the death of the younger son.

\section{A Troubling Foremother}

Further up the family line there is a more problematic female ancestor. Her great-grandmother (mother's mother's mother), after bearing a son and a daughter, had several abortions because of the family's poverty and her duties to her mother-in-law. Then came a pregnancy she could not abort, though she tried. She dreamed of a woman named Jin sitting on the chamber pot calling to her and woke to see a stain of fresh blood on the top of the bedcurtain. She asked her mother-in-law and learned there had indeed been a great aunt Jin in the previous generation who had died of complications in childbirth. She knew she was doomed. She cried out piteously and died, her belly still tight as a drum (Lü 1930, p. 7; Lü 1941a, p. 51). The narration in the Suibi differs on the details of the number of children and the number of abortions and excludes vivid physical details.

In Yinweishi bilu, Lü's closing remark, absent in the Suibi, laments that such a filial daughter-in-law should die for harming life. Two different views of abortion, the matter-of-fact and sympathetic presentation of a woman making a pragmatic choice for her family's sake and an absolute condemnation of the taking of life, clash between tale and comments. Moreover, within the tale, her death is not caused by revenge of the aborted fetuses but follows the type of the ghost of a woman who had died in childbirth taking a substitute. ${ }^{14}$ The terror of the dangers of childbirth lingers in both interpretations.

Although he is discussing events during his own lifetime, Guo Zeyun's treatment of his sister's affliction by a childbirth ghost is much more abstract. When she is suffering from postpartum illness and he comes to visit her, she always urges him to go away, secretly telling others that when he is there the ghosts by her side get restless. In hindsight, their discomfort was probably triggered by Guo's future examination success; high academic status and political office are often thought to have an exorcist effect. After she dies, an uncle's wife on the brink of death from postpartum complications sees this sister calling to her (Guo [1936] 2010, 6.300). Unlike the case of Lü Meisun's great-grandmother, I infer that this aunt had known Guo's sister and needed no external confirmation to recognize the figure in her vision, thus this vision could be read as her fearful memory of a family precedent. Speaking in neutral terms, Guo takes his sister's experience and her appearance as a ghost as evidence of the reality of the phenomenon of substitute-seeking. However, he follows with another story from a different family in which a woman with postpartum illness sees the ghost of a woman who had died in childbirth in the same room but still survives, demonstrating that those who are not fated to die are not vulnerable to such ghosts, and effectively containing and rationalizing the threat. No one in this story sees blood or other physical details which should be concealed from a young man of the family, nor are there any strong expressions of fear or grief. He analyzes this grim family legacy, transmitted woman

14 In contrast, in one of his plays the late Qing moralist Yu Zhi 余治 (Yu 1873) depicts a monstrous, vengeful infant as the retribution for female infanticide. Yu guai tai 育怪胎 in Shujitang jinyue 庶幾堂今樂 volume 3. 
to woman across boundaries of the patriarchal family (as his sister returns to her natal family to take her substitute), from the safe perspective of a man, moreover a man ghosts would not lightly approach.

\section{Fates of the Sisters}

As with her eldest brother, the deaths of the two of Lü Meisun's sisters appear in Mianliyuan suibi as evidence for destiny and interaction with souls of the dead. By her account, her eldest sister Lü Huiru (1875-1925) was upright but overly conservative. When she was principal of a girls' school in Nanjing, she demanded the harsh punishment of a math teacher from another school who was courting one of the teachers under her supervision. He ended up dying in prison, at which she felt deep regret. Years later, after her retirement as principal, she descended into madness, running into the streets crying and laughing. In a lucid moment, she told Meisun that this was retribution. One afternoon, the soul of the wronged man had called on her, and from that moment she lost control of her heart and spirit. Meisun told her that an unintentional wrong should not cause a longing for vengeance (though it is evident from both her brother's and father's stories that she does not consistently believe this), but also plans to seek out the man's family and anonymously send money to the survivors in order to placate the wronged soul. She was, however, "prevented by people", and her sister ultimately died (Lü 1941a, pp. 73-74).

Her sister's story seems to stand at the borderline of speaking about mental illness in demonic and medical terms, but Lü Meisun suggests a deeper underlying cause for Huiru's flaws. In the final sentences of the story Lü Meisun recalls that their mother had at the moment of her sister's birth dreamed of going into a shop and seeing a merchant leaning over the table, using an abacus to settle his accounts. And indeed her sister's face resembled the person glimpsed in a dream, and before the age of 10, had not been good at reading, but only at arithmetic (Lü 1941a, pp. 73-74). A mother or other family member's dream at the moment of a child's birth granting a glimpse of an earlier life is commonplace, but the ones recorded are nearly all positive or neutral images: either a divine being or, most commonly for men, a monk. ${ }^{15}$ For Lü Meisun, influenced by literati prejudices, the image of a merchant seems to suggest intellectual and spiritual limitations, including an overly close calculation of wrongs. The transformation in gender between lives is left without comment. From a traditional perspective, for a merchant to be born into a jinshi's family suggests a promotion, but for a man to be born a woman is a demotion. Lü Meisun's narration of her mother's vision of her own past incarnations will be discussed below. The transformation from only being good at calculations to a poet and painter suggests the environment of a literati family overcoming the inborn legacy of a former life. In her additions to their father's autobiography, Lü Meisun describes teaching the then 12-year-old Huiru how to paint as one of the few comforts in his final, grief-stricken years (Lü Fengqi 1934, p. 50b). As she weighs several sources of fate-familial legacies of good and evil deeds; one's own karma from past lives; one's deeds in this life; and inborn personality strongly linked to earlier lives-she remains ambivalent about which ends up being the most important. Although her elder sister was already dead by the time she composed the Yinweishi bilu and it would seem to fit the theme of retribution, she does not include this story in that book.

The sisters have four distinct paths, depending on their ages when their father had died. Meisun sees her youngest sister Kunxiu (Xianman) as the most pitiable, having enjoyed the fewest years of prosperity and stability, and being the last to become independent enough to fend for herself. Illness causes her to interrupt studies in Shanghai and return to Anhui with their mother, where they are abused by relatives to the point that both attempt suicide (Lü 1941a, pp. 89-90). Although she also had a brief career as an educator at a woman's college in Jilin, she never married so that she could care of their mother while the other three earned their living elsewhere in China. Lü Meisun presents

15 Guo Zeyun records several stories of this type (Guo [1934] 2010, 2.29-32). 
herself as evolving from her father's legacy of skepticism about the spirit world to later approach her mother's piety, but her youngest sister was always a believer.

The tales related to Lü Kunxiu's death are premonitions rather than causes, and there is no suggestion of an underlying flaw in her character. (I am telling the stories of their deaths in the order of their seniority in the family, not chronology; the eldest sister outlives the youngest.) First, she has a dream of receiving a letter from a recently deceased maid, which she takes as an omen of her own imminent death (Lü 1930, pp. 19-20; Lü 1941a, pp. 57-58). After their mother's death, Lü Kunxiu wanted to follow her in death. When they are preparing to leave for Xiamen, where Lü Meisun had a teaching position, she hears a loud boom from inside the luggage, which she interprets as her mother's spirit. When she prompts, "If it is ill-fated for me to go to Xiamen, make the sound again," the sound repeats. She is unwilling to go until Meisun forces her, and indeed falls ill a few months after arriving there. She insists she will become a ghost who will protect her sister and asks the servants to burn spirit money for her, since her sister did not believe her, saying she will manifest as a whirlwind when offerings are made. And, as foretold, over the next several years there are mysterious noises and whirls of air, one of which saved their elder sister from an outbreak of fire, one of which tried (unsuccessfully) to prevent Meisun from going to a place where she falls severely ill, and some of which have no such clear meaning but just prove Kunxiu's presence. After a few years, this ceases, and Lü Meisun assumes that she has gone on to another incarnation (Lü 1941a, pp. 89-93). The younger sister as a protective presence is another manifestation of a woman-centered view of family.

The memory of Lü Kunxiu lingers in more than one way. She is the most frequent subject for mourning poetry among all the kin Lü Meisun has lost, and the subject of new poems 20 years after her death (Lü 1931, pp. 54a-55b, 83b; Lü 1933, pp. 24b, 67a-68; Lü 1934, pp. 11b-12a; see also Xu 2015, pp. 189-90). Since Kunxiu is the most devout believer and then the most commonly appearing ghost, the accuracy of her prophecies combined with guilt plays a part in Meisun's spiritual development from skeptic to transmitter of ghost stories.

In matters of death and remembrance, Lü Meisun reveals the new structures of the family. With great difficulty and what she perceives as intervention by Kunxiu's ghost she buries Kunxiu with their mother in Shanghai (Lü 1941a, pp. 89-93). She makes no mention of attempting to bury her mother with her father back in Jingde; presumably the ill-fated family gravesite was part of the property from which they were disinherited back in the 1890s. ${ }^{16}$ Later, when she has settled in Qingdao, she buries a lock of her mother's and Kunxiu's hair together so that she has a more convenient place to make offerings of remembrance (Lü 1934, pp. 11b-12a). She describes having her son to serve as heir also for Kunxiu; there is no such tradition of sharing an heir between sisters, since an unmarried girl should have no heir and the child would be of a different surname. Lü Meisun is invents a tradition, performing the duty a surviving brother might have undertaken for a deceased one (Lü 1933, p. 68a). ${ }^{17}$

During the years between the composition of her two different tale collections, Lü Meisun also takes on the traditional responsibility of printing the remaining works of the deceased, arranged in order of seniority in the family: father, eldest sister, youngest sister. The samplings of her sisters' poetry that she can reproduce are the chance survivals of different stories of loss. With the new access to the means of publishing available to her generation of women, daughters and sisters can take on the responsibility once usually assumed by sons and brothers.

16 I am not sure where Lü Huiru was buried (she died in Nanjing), though Lü Meisun seems to have managed her funeral as well and then assumed responsibility for her orphaned daughter (Xu 2015, p. 275). Lü Kunxiu was only allowed to be buried with their mother because of an exceptional circumstance; policy had changed so no more Chinese were allowed to be buried in the foreign concessions in Shanghai.

17 Not having her son be heir to Lü Huiru as well could reflect the fact that Huiru had been married (at least briefly) to one of their Yan cousins. 
Lü Bicheng is the one sister who scarcely appears in her elder sister's tales, perhaps because she is still alive and speaks for herself. But she also features only minimally in Lü Meisun's poetry. ${ }^{18}$ There is a conspicuous silence between the surviving sisters in the world of print. In a comment to one of her lyrics, Lü Bicheng says she has cut off communication with her one surviving sibling for 30 years (Lü [1937] 2017, 1:3.33). ${ }^{19}$ Nonetheless, they work in parallel on the projects of family memory. Both of their names are listed as editing their father's surviving works, but Meisun writes all the postfaces and epilogues, and Bicheng's comment makes me think that the older sister included the younger sister's name without her actual involvement. Lü Bicheng also prints some of Huiru's poetry, a larger corpus than Lü Meisun could gather, appended to her own works (Lü [1937] 2017, pp. 469-79). They have a shared interest in Buddhist faith and karmic retribution, but Lü Bicheng does not use her own family as a primary public example.

\section{The Self at the Pivot of Karma and Consequence}

Where does Lü Meisun place herself in this lineage of gendered karmic consequence? Already in the preface of the Yinweishi bilu, she writes in an autobiographical mode. Under a diagram of a cycle from poverty to self-improvement to prosperity to self- destruction, she narrates her own life in these terms. At the beginning she was poor and in difficulty, then she regretted and understood; then because of that enlightenment she practiced diligence, from her diligence knew frugality; from her frugality she gradually become prosperous; but after becoming prosperous, she became arrogant and practiced extravagance, self-indulgence and violence, which of course summoned disastrous changes, returning to poverty (Lü 1930, inside cover). This suggests that she composes this volume at the point of turning to regret and enlightenment again.

A story of being mysteriously rescued from a fire is shared in both collections. This incident appeared right after she had completed the Yinweishi bilu and was preparing to publish it, so it appears in that book as an appendix after the other stories. Alone in her house with only her son and a deaf old servant, she sleeps with the windows closed because the air is strangely cold and oppressive. Then she falls into dream paralysis and cries out, woken by her son also crying out. Later, it seems that someone was pushing her, and when they both woke, they discovered that an electrical wire on the ceiling had started a fire. It was only inches away from igniting the bed-curtains. She gets up quickly and turns off the power, but had the fire spread the three of them would certainly have died, even more because she had recently doused the beds with oil to kill insects. In the Suibi she attributes it to the protection of "ghosts and gods", in the Yinweishi bilu to either that or the intervention of her parents' spirits (Lü 1930, pp. 36-37; Lü 1941a, pp. 55-56). Modern conditions of living created new hazards, but protective presences remain efficacious.

A more dramatic incident of miraculous survival provides the capstone of a complete spiritual autobiography. In contrast to the narrative structure of Lü Huiru's story, which offered an earlier incarnation as an explanation at the end, Lü begins her own story with her mother's dream at the point of her birth. "In the seventh year of the Guangxu reign, my late mother Lady Yan was pregnant with me in the capital. When she came to term and was about to give birth, her abdomen was in extreme pain, and blood filled the mat. Suddenly she dreamed that she entered a place divided into light on the left and dark on the right, and she stood on the left. In the dim light on the right she saw a man, about thirty years old, with a prominent nose, a large chin, and a refined manner. She knew in her heart this person was cultured but degenerate, a poor licentiate working as a scribe writing lawsuits. Just as she was looking at him intently, the person suddenly changed into a woman, of the same age and face, wearing a green cotton shirt and skirt and black cloth shoes, all impeccably clean. In her hands

18 One mention is in a poem in which Meisun reflects that of the six siblings, only two survive, but her sister lives in a foreign country 10,000 miles away (Lü 1933, p. 77a).

19 For discussion of the rift between the sisters, see (Xu 2015), pp. 22-24. 
she had a basket holding scissors, needles, cloth, thread, a fulling mallet, a short bench, and scraps of cloth. She sang, 'Whoever has soiled clothes, I will wash them for you; whoever has torn socks, I will mend them for you." Mother again knew in her heart this woman was the wretched licentiate's reincarnation, her clean clothes and shoes were perhaps the ones she was buried in. The woman came close and threw down her basket, all her belongings scattered on the ground. She turned and jumped towards my mother. Mother woke started, and I was born immediately. When she asked, she was told she had given birth to a girl. Mother was silently unhappy, knowing that this girl's karmic roots from her previous two lives were too base, so that she would certainly have neither fortune nor longevity." (Lü 1941a, p. 84).

The details of the blood of childbirth and the implements carried by an itinerant seamstress are reflective of a story narrated by a woman. Her parents' reaction to the vision of her previous incarnations makes as powerful an impression as the incarnations themselves. Her mother concludes that Lü Meisun's inborn nature dooms her to be poor and not to live past 30. Social class and personality seem more essential to identity than gender. The man who uses his writing brush for others instead of in pursuit of his own career is made equivalent to the woman who sews for other families rather than for her own. Her father, when he sees the infant Meisun, says he does not love this child, and suggests she could be raised by a maid. Meisun concludes from this response that he must have had the same dream as her mother. Her mother keeps the dream a secret, fearing she will not live, but sees confirmation of it in a childhood incident, when the one-year-old Meisun weeps to see a single copper coin abandoned on the ground. Her father's early lack of affection for her as an infant is most likely also learned from her mother's telling. Her mother tells her the story when she reaches the age of 12 sui, perhaps thinking this is when she could effectively learn from it.

The account of her previous lives appeared in print several distinct times: in her second poetry collection in autumn 1933; as a story in Guo Zeyun's first collection in 1934; in a Buddhist periodical in early 1941; in the Mianliyuan suibi in autumn 1941 (Lü 1933, pp. 49b-50a; Guo [1934] 2010, 7.140; Lü 1941b). ${ }^{20}$ Interestingly, the earliest version only includes the female incarnation, not the male, and an earlier poem recounting her birth in Beijing does not mention it (Lü 1931, p. 4b). This suggests that the story continued to evolve in Lü Meisun's memory long after her mother had told it, and it was not essential to every version of her early life.

These tales of reincarnation explore the point at which family history meets an alien history. The newly born child is at the same time a stranger who has taken refuge, who must be taught to overcome the karma from past lives. At the age of seven or eight the perspective shifts to her own recollections of childhood mischief and disobedience. This makes it an extraordinary female autobiography. To criticize oneself as not adequately filial is conventional, but Lü Meisun details her revenge on a strict teacher and a concubine who is plotting to run away in vivid terms. The frame of a confessional narrative allows inclusion of behaviors otherwise unthinkable to describe for a girl.

After her father's death, when the widow and her daughters are in desperate straits, oppressed by paternal relatives who are seizing their inheritance, Lü Meisun, now 14, vows to Guan Yu and the City God that she will spend her life as a female doctor to support her mother, never marry, and stop eating meat if they are rescued. Were she to break the vow, her head should be severed. Around the same age, she helps her family writing the suits to try to reclaim lost property, feeling that she has done this before.

Though she becomes an educator rather than a physician, she is accurately foreseeing a future of financial independence that would have been harder to imagine one generation earlier. She probably assumes it is her responsibility to make this vow because her elder sister has married. The gods to whom she chooses to make the vow are male, concerned with the male-dominated process of administering justice, and not usually associated with the Buddhist elements of her oath.

20 There are also some textual differences between the final lines of the poem in the poetry collection, newspaper, and Suibi. 
After she had achieved some financial security as a teacher in Tianjin, however, influenced by the new learning that dismisses beliefs in ghosts and gods as superstition, she breaks her earlier vow, writing a letter to her mother saying that if her mother still believes in ghosts and spirits, she will come home and kick over the incense burner. Then, one day in 1906, she is involved in a collision between a streetcar and her rickshaw that almost severs her left hand and leaves her unconscious in the hospital for days. ${ }^{21}$ It is 10 years later, after working in women's schools in Fengtian, Fujian, Nanjing, Shanghai, and Anhui, that she establishes the interpretation of her accident. "Hand" 手 is a homophone with "head"首, and the gods have been merciful to her, modifying her excessive vow and injuring her left hand rather than her right, which she must rely on to earn her living wielding her brush. Through this protection, she has been able to go beyond the fortune and lifespans of her two earlier incarnations, at the time she writes this having lived to the age of 60 . She writes this as a lesson to all who do not believe in karma (Lü 1941a, pp. 84-86).

She does not remember the accident herself but has entirely taken over the role of narrator and interpreter. The interpretation of this incident takes longer than that of rescue from the fire. The unnamed and unpersonified forces of justice use a new feature of her urban environment, the electric streetcar that had just started that year, as the means of her punishment. But unnamed gods also recognize the need of a woman to make her living by writing. She acknowledges the kinship of her work as educator and writer to the scribe and seamstress for hire she was before, but she has been able to survive twice as long. Two incarnations, one female and one male, were needed to decipher her life.

Guo Zeyun relates a simplified version of Lü's conversion story, from her mother's vision to Lü Meisun's accident. He does not include the details of her childhood disobedience and describes her return from disbelief to belief in only a few sentences. His wording suggests he may have heard the story from her orally. To it he appends a summary of a family story that he states explicitly is from the early pages of the Yinweishi bilu, Lü's great-grandmother's generosity rewarded with additional years of life (Guo [1934] 2010, 7.140). As will be discussed below, Guo is interested in the continuities across generations, including among women.

\section{The Male Line}

Guo Zeyun's Jiude shuwen is structured following the generations of the patrilineal family, from the first juan on the earliest ancestors to the sixth juan on his own generation. Women appear where they fit into the patrilineal family as wives or concubines, or as sisters contributing to familial memory as writers. Dongling xiaozhi is nonlinear, with a concentration of family stories at the very beginning of the first juan, and reflects an inclusive definition of kinship, reaching to include his famous in-laws, the $\mathrm{Yu}$ 俞 family of of Deqing, and the relatives by marriage of his sisters. Guo sometimes offers two inter-nested visions of family continuity, one male and the other female. The very first story relates his father's recurring dream, the second tale is Guo's wife's dreamlike encounter with the spirit of an aunt who had died of suicide (Guo [1934] 2010, 1.7). Guo's second collection starts with his own prophetic dream of a garden where he later lived, suggesting a generational structure (Guo [1936] 2010, 1.173).

The tale about his father Guo Zengxin's郭曾炘 (1855-1928) recurring dream appears in different versions in Dongling xiaozhi and Jiude shuwen (Guo 1936, 5.19a-19b) The dream is the same: among misty peaks he crosses a white stone bridge, finding an imposing office where the people working recognize him as one of them. In each case after his father's death someone else has a confirming dream of visiting this same place: in Dongling xiaozhi, it is one of Guo Zeyun's male friends, Yang Shounan 楊 壽楠 (1868-1947), and in Jiude shuwen, it is Guo's younger sister Baoying 葆英, who had collapsed in grief. Yang had gone together with Guo himself, and Guo's father turns them away, saying they do not belong there. Baoying is turned away by door guards without seeing her father, who is referred to by a former name that she had not previously known. The dream of an otherworldly office is a

21 See also (Xu 2015), p. 265. 
recurring theme in late imperial dream tales. For Guo's father, in middle age, it offered an image of continuing meaningful work in the face of his own mortality. In the same way this tale is a comfort for the survivors, giving their elder a continuing respected role, even if the nature of that role remains opaque. The reassurance at the same point marks the separation of the living and the dead: Baoying cannot see her father, and even the less emotionally involved Yang cannot linger in this place. Jiude shuwen is focused on familial experience while Dongling xiaozhi includes a larger circle.

The disturbing but domesticated memory of Miss Zhou, the first betrothed of Guo's grandfather, appears in both books, including as the fourth story in Dongling xiaozhi. The outline of her story is shared in both versions: after the death of her mother, a conflict with her father's concubine drives her to suicide. Her fiancé dreams of her, and only afterwards learns the news of her death. Subsequently he marries Guo's grandmother Chen, and they have a son and a daughter. Their son, who will become Guo's father, is sickly, and Chen dreams of Zhou telling her she will protect the children if they are made her heirs. She is added to the sacrifices, and Guo's father survives (Guo [1934] 2010, 1.8; Guo 1936, 4.12a).

Beyond the shared outline, the discrepancies between the two versions reveal generic differences. Only the zhiguai details the cause of her death: as she suffered from abdominal swelling, her concubine stepmother accuses her of being pregnant, coercing a doctor to confirm it. She cuts open her own abdomen to prove her innocence, so her fiance's dream of her is correspondingly more graphic: she appears bathed in blood. The zhiguai also includes more ritual detail about how she is incorporated into their family: following Fujian custom, they receive a pair of embroidered shoes and then set up her spirit tablet. In Jiude shuwen, only taking the son as her heir is mentioned, rather than both the eldest son and the eldest daughter. The zhiguai concludes with a reflection on the transmission of the story and a quote of Guo's brother-in-law urging him to record the story. Jiude shuwen instead closes noting her male kinsmen (two nephews, sons of her brother(s)) and their ties to Guo and his brother. The placement of her story also reflects the overall structure of the two books. Jiude shuwen seems to reflect her position on the family altar, after a concubine who came in the family later than she did, because Zhou is neither concubine nor wife. In Dongling xiaozhi Guo is instead free-associating on the theme of family dreams and visions.

Guo's grandfather's dream of her confirms their connection, but it is his grandmother's dream that leads to ritual action converting a baleful soul into a protective ancestor. Both the man and the woman who dream of her feel a mixture of sympathy and dread. The element of threat to the children is better concealed in this tale than in Lü Meisun's story of her mother's dream of her former mother. When Miss Zhou offers herself as a protective ancestor, she no longer appears as bathed in blood.

Jiude shuwen suggests the range of strange experience which is acceptable in a history of family virtue: patterns of destiny (such as the tendency over generations for second sons to die young); visions of divine positions for deceased kin; divination and prophecy, especially exam-related omens; humane but firm dealing with haunts; miraculous cures from illness; and successful divine intervention, as when a talisman prevents a fire. ${ }^{22}$ Dreams are a frequent medium for many of these links between levels of reality and moments of time, lying as they do between the quotidian and the extraordinary.

In stark contrast to Lü Meisun's mother's dominant presence in the collection, Guo's mother is a painful absence. After she bore his older sister, the next two years went without another pregnancy. She dreamed that Guanyin told her that she was not destined to have a son, and if she was to do so she would have to give up some of her own lifespan. She eagerly agreed. In her final illness, the infant was kept away from her, so he reflects with regret that it is as if she had no son (Guo 1936, 5.4a-4b). All he has been able to do to repay the mother who traded her life for his is to repair his heirless maternal

22 On second sons, (Guo 1936, 2.5b); on a vision of his great-grandfather as a judge in hell by a kinsman in the next generation, (Guo 1936, 2.11b); on divination and prophecy, (Guo 1936, 2.16b-17a, 3.20b-21a, 4.10a, 5.4b, 6.1a, 6.16a-16); exam omens, (Guo 1936, 2.20b, 3.15a, 4.9b, 5.4b-5a); a medicine granted in a dream, (Guo 1936, 3.17a); on the talisman avoiding fire, (Guo 1936, 4.7b-8a) as well as in (Guo [1934] 2010, 4.80). 
grandfather's tomb and grant him rank. It is unclear who would have told Guo about his mother's dream bargain, now central to the memory of the parent he was too young to remember directly.

Two of the later entries in Guo's last collection Dongling buzhi are retellings of Lü Meisun's family stories. The first is the tale about the servant seeing the ancestors returning to receive the Qingming sacrifices, including the two unmarried girls, which he says he heard from her directly. Guo tells it to chasten himself, concerned that with his family scattered in different places the death-dates of ancestors are easily forgotten (Guo [n.d.] 2010, 1.388). The second is the tale of her maternal grandfather and her uncle's delivery from Taiping capture discussed in detail below, including quotation of her poem on her uncle's rescue (Guo [n.d.] 2010, 1.389). Guo uses it as an illustration of ancestors' continued concern for their descendants. Receiving Lü's tales by both oral and written means, he recognizes their common concern with family.

The ancestral altar is a place of central attention for Guo. His brother who died young had a vision of receiving family offerings (Guo [1934] 2010, 2.44). A young man who had forgotten to include a concubine-grandmother in offerings has a dream of her saying, "I came to eat." (Guo 1936, 6.3a) Guo himself carefully researched the correct ritual for making a replacement spirit tablet for his mother that would include the rank he had won for her, at the same time as making a tablet for his stepmother. While the tablets are being transported back to the ancestral home, his aunt has a vision of the two mothers together. Since she had never known Guo's mother, being able to describe her appearance confirms the dream (Guo [n.d.] 2010, 1.396). Men and women of multiple generations, both the living and the dead, work together to insure completeness of both memory and ritual practice. Lü Meisun tells the tales but has probably abandoned hope for a complete ancestral altar.

\section{Legacies of the Chaos}

Underlying the succession of generations is history on a larger scale than the individual family. Born in the early 1880s, in their 30s at the establishment of the Republic of China, and writing in the 1930s, Guo and Lü share a historical orientation. The earliest horizon of memory for Lü Meisun, whether for stories of her own family or others, is the Taiping civil war (1853-1864) and the decades immediately preceding it. ${ }^{23}$ This reflects generational time, as events $20-30$ years before her birth were living memory for her parents' generation. Her mother was 8 at the time when the Taipings took her hometown, her father was 16 at the outbreak of the rebellion and 23 when he was forced to become a refugee. This frame of reference also highlights the importance of this period as a traumatic turning point in Chinese history overall, particularly for her home province of Anhui and all of Jiangnan. ${ }^{24}$ For Guo Zeyun the Taiping war is a source of lingering haunts, but fewer of his own family tales deal with the lived trauma, largely for geographical reasons. The Boxer Rebellion and the Xinhai revolution have a more significant presence. ${ }^{25}$

The separations of the rebellion produce many different threads of family history. Her maternal grandfather is captured in Nanjing where he had gone to take part in an examination. Taking refuge in a temple and considering suicide, he is comforted and nursed back to health by a mysterious Mr. $\mathrm{Hu}$ whom he later concludes is a fox spirit. Her oldest maternal uncle, 14 at the time, is captured in their hometown but later contrives his escape, urged to do so by a vision of one of his ancestors.

23 The first story in Yinweishi bilu, “Seng bao yuan" 僧報怨. begins with a wrong done in the time of the suppression of the Taipings, with consequences carried out a generation later. “Niefu zhibao" 逆婦之報 also has the Taipings as the final instruments of justice destroying an unfilial woman, 6 . In contrast a man is rewarded for both his military resistance and his rescue of refugees with the prosperity of his descendants, 蔡總兵善行 Yinweishi bilu, 13. 蔡總兵Mianliyuan suibi 23-24.

24 For more see (Meyer-Fong 2013).

25 Fox encounter foretelling the displacement of the Boxer Rebellion, Jiude shuwen 5.8b-9a. A servant encounters a ghost while he has travelled south to avoid the Boxers, (Guo [1936] 2010, 4.201); omens before the Boxer Rebellion breaks out (Guo [1936] 2010, 7.328). Guo was also the author of an entire collection of poetry recounting the rebellion, Gengzi shijian 庚 子詩鍳. Guandi descends to the planchette to say that the Qing had been destined to fall (Guo [1934] 2010, 2.28); Foxes foresee the Xinhai Revolution, (Guo [1934] 2010, 5.288). 
Her maternal grandmother and the younger children are refugees in the mountains, surviving eating weeds (Lü 1941a, pp. 98-99; Guo [n.d.] 2010, 1.389). Later, she is summoned by her father and goes north to Beijing with their children, so that although she avoids the war she is subjected to the situation with the insane kinsman described above (Lü 1930, pp. 9-10; Lü 1941a, pp. 53-54). Her earlier extreme filial care of her mother-in-law is credited with the survival of the entire next generation, nine people in all including her children and their spouses, when in their home county of Lai'an there was hardly any family, with three survivors (Lü 1930, p. 11; Lü 1941a, p. 15). An aunt who carries her parents-in-law's remains with her through all the displacement of the rebellion is rewarded with good careers for her children (Lü 1930, p. 11).

Her maternal grandparents' separation, with her grandfather captured by the Taipings, allows another extraordinary woman to enter the family history. Zhang Guose 張國色 ("National Beauty", a nickname) was a scholar's daughter from Yangzhou, who was able to avoid molestation by both the Taiping soldiers and the Heavenly King Hong Xiuquan himself by cleverly submitting herself to Hong Xiuquan's wife as a foster daughter. She gains high office and is the one who suggests an examination for women. But Hong's wife remains suspicious of Hong's attraction to her, and hastily arranges to marry her off to Lü Meisun's captured grandfather while the king is occupied on the battlefield. Her new husband warns Zhang both that he plans to escape and that he already has a wife, whom he does not know is alive or dead. If his wife has survived, Zhang's status will be that of a concubine. She agrees to both of these terms, and they succeed in escaping at the brink of the Taiping defeat. She is taken back to his hometown. When Lü Meisun's grandmother and Zhang finally meet when the former leaves Beijing, Zhang fulfils the obligations of a concubine serving the first wife impeccably, winning the love and respect of her superior. The account closes with Zhang's recollection of the Taiping leadership as capable but destroyed by infighting. ${ }^{26}$

This is a fascinating reevaluation and, to some degree, romanticization of the Taiping movement. Zhang's canny and staunch protection of her chastity places her on a path to enjoy power and privilege unavailable to women outside of the Taiping controlled area, and she uses it to further promote women's education and status. The Taiping examination for women had been regarded with derision by literati writers of the decades after the civil war, ${ }^{27}$ but here it is cast in a positive light. Zhang's lack of an identifying name makes her even more the stuff of legend, claiming a position close to the Taiping leadership I have been unable to verify in other sources. A relationship forged under unusual circumstances is beautified, and one suspects less sexually and politically chaste versions of the pairs' history have been suppressed. ${ }^{28}$ By the end of the story, Zhang shifts again to complete submission to the hierarchies of the polygamous system. A Guangxu-era story that must defend the choices of men and women living under Taiping rule rather than committing suicide, and must make a relationship formed under politically dubious circumstances legitimate, is contained within a later reevaluation of the Taiping movement as having positive potential, particularly for women. It is tempting to assign the conservative voice to Yan Shiyu and the revisionist history to Lü Meisun, but transmission may be much more complicated. Zhang's story is not included in the Yinweishi bilu perhaps because there is no clear moral to be drawn; until the end when she redefines herself as exemplary widowed concubine, she is defined by her beauty, talent, and resourcefulness rather than her virtue.

Zhang's story is all the more interesting when contrasted with the story of Yan Shiyu's cousin Lady Chen, a celebration of a chastity martyr much more typical of Guangxu-era discourse about the civil war. Also a renowned beauty of her native place, she chose to be dismembered piece by piece rather than submit sexually to the Taiping forces. Afterwards, she appears in a dream to both her

26 “Zhang Guose" 張國色, Mianliyuan suibi 4-6.

27 For one example, see Xu Feng'en (1996), “Shu Fu Shanxiang” 書傅善祥 Lantiaoguan waishi 10.351-353.

28 Guo Zeyun's grandfather also had a concubine Jiang Yunlan whose family had been displaced by the war; Guo's great-grandfather "got her from among the army" 得之兵中 and insisted his son take her. This brief expression suggests but elides a history of violence and coercion. She, too, is celebrated for her virtue and modesty (Guo 1936, 4.11b). 
sister-in-law and Lü Meisun's grandmother, revealing she has been rewarded with ascent to heaven. Yan demanded in tears that her daughter write a poem celebrating this kinswoman (Lü 1931, 10a-10b; Lü 1941a, p. 97). The dreams themselves and their transmission are all conversations among women. Unlike Zhang's story which contained multiple layers of interpretation from both different generations and different family members, Lü Meisun fulfills her mother's assignment by recording Chen's story entirely in terms acceptable to the prior generation.

The tales from the Taiping years reveals the narrative flows in the family. Although according to her father's autobiography her paternal family's experience of the civil war was harrowing, with fewer survivors than the Yan family, it rarely enters these pages. This reflects both her mother's sixteen-year longer presence telling stories as well as her father's reluctance to frame survival and destruction in karmic terms.

I have written elsewhere about how an age of chaos is a time of heightened karmic stakes and thus more likely to produce exemplars (Huntington 2005, pp. 73-74). Lü Meisun's collections illustrate how this continues to resonate through the following generations. Although the historical evaluation of the Taiping movement could change, the familial accounts of survival and loss remain.

\section{Karma and Change}

In their prefaces and tales, both Lü and Guo address the cultural differences between the world of their childhoods and the worlds in which they wrote. In her short preface to Yinweishi bilu, Lü Meisun argues that one cannot assume that because one has not seen something that it does not exist. If you told people 100 years ago you could cover distances of 1000 li in a day's journey or talk with people in another province, they would have dismissed it as nonsense. The way that disciples of the "new learning" (meaning Western science) look at reincarnation of people and animals and retribution for good and evil is just like the people of the past laughing at cars and telephones (Lü 1930).

She argues that technological advances, rather than disproving the existence of the spirit world, demonstrate the possibility by analogy. She ties transformations in communication and travel to what should be unchanging principles of karmic consequence that link together apparently distant lives and deeds. Placing tales from the Guangxu era and recent stories side by side, although there are more old stories than recent ones, is itself an argument for that continuity. As the stories discussed above demonstrate, people living in the Republican era are linked to the imperial past by familial legacies of good and evil, as well as their own former incarnations. The two basic models of connection between the late Qing past and the Republican present are haunting and karmic consequence; the former is more temporary than the latter.

One of Lü Meisun's neighbors, a student at a women's school in Shanghai, had been haunted through her adolescence by the ghost of her wetnurse's husband, who had died as a consequence of opium addiction. He appeared in old style clothes and hat, the opium pipe still in his hand. When he came, she would suffer from fever, chills, and headache, and she would quickly burn spirit money to send him away. When she was 23 , she married, and he did not come again. Lü interprets this in a way that does not fit into a framework of retribution: this is a ghost who because of his poverty had no other choice but to disturb the child his wife had raised. But after she married, he could not bother another household, so he did not come. Lü respects him for being reasonable in this way (Lü 1930, pp. 5-6).

The dates in the story are unclear, but one of the modern generation of educated women being haunted by a ghost from another time and another class, is a remainder of an extended vision of kinship. His old-fashioned clothes and opium pipe make him almost a caricature of unsettled memories of the end of the Qing. He vanishes not because of the march of historical time or her education, but by the shift of her family status that would have been no different in the nineteenth or the twentieth century: after her marriage she is no longer the surrogate daughter of his wife.

Another female friend dreams of a servant she had saved 38 years before, warning her to move away from a tree, because it was going to crush her. Three days later she is avoiding a runaway car, sees a tree where she might take shelter, and runs farther. The car hits the tree and it collapses, 
but she escapes with only a bump on the head (Lü 1930, pp. 28-29). The servant communicates about the part of the accident that would have made sense in the past world where she had saved him. Guo Zeyun similarly relates a tale of a man saved from a train accident in Tianjin by the spirit of his grandfather (Guo [1936] 2010, 3.240). In both accounts the careening vehicle cannot be controlled, but with otherworldly help from a past before these technologies, humans can move out of the way.

Like Lü Meisun, Guo concludes that as people were influenced by modern learning, they no longer believed in karma, and as a consequence people did evil all the more. Nevertheless, he has seen overwhelming evidence of retribution. The example he cites, heard from an acquaintance, occurred in about 1919-1920 in Beijing. A man who finds an abandoned infant wrapped in a fox fur with a sum of money asking someone to care for him/her, takes the goods and crushes the child with a bicycle, and then discover the same day his own small child had stolen out of the house to play and had been crushed by a car (Guo [1936] 2010, 3.241). As in Lü Meisun's own accident, the hazards of the modern city become the means of swift karmic repayment.

Other tales confirm the undiminished value of ritual action. In one of Lü's stories the colleagues of a teacher at a Western-style school in Nanjing fail to take him seriously when he asks them to block the path of an infernal emissary coming to take him away, but he is vindicated by his death (Lü 1930, pp. 6-7). Funerary goods as a tie between the living and the dead also retain their value in the changed world. A Guo nephew, who had drowned studying in Japan, appears to his birth (concubine) mother, from whom his death has been concealed, seeking clothes (Guo [1936] 2010, 6.304). Another tale of a recent death confirms the usefulness of spirit money with a dream of the departed, though before the dream, the living had joked that with rampant inflation in the world of the living, the currency may not be valuable for the dead (Guo [n.d.] 2010, 1.387-388).

In other tales, Guo addresses the issues of cultural change outright. In a tale of a virtuous official becoming a City God after death, Guo Zeyun wonders why, when the cult of the City God has declined in the world, the institution still exists in the netherworld. One of his friends answers that whatever exists in the human mind will exist in the netherworld, be it the Mountain of Knives or King Yama and the judges of Hell (Guo [1934] 2010, 1.11). This logic however suggests only a delay in the abolition of the pattern of virtuous local officials continuing their work as City Gods. When the last of the Guangxu-era exam graduates who have this expectation die, then there will be no more City Gods.

As he had started his first collection with his father's dream, he ends with a dream of his own that he had in 1930. He dreams of going to a heavenly palace, with people in ancient clothes. They say this is the Bureau of Managing Letters司文院, and all the books are indecipherable seal-script. He asks them with the way of the world changing, does the way of heaven not change? An unidentified old man replies that although there is a cycle of transformation, heaven and the way are constant (Guo [1934] 2010, 8.168). The dream asks the question: will a meaningful place remain for him on another plane, as it did for his father? The answer is reassuring, though the discussion of the City God seems to imply only because he so devoutly wishes it to be so.

\section{Conclusions: Stories between the Family and the World}

One of the challenges of family history in the mode of the didactic tale is honoring and grieving the dead at the same time as establishing individual and collective responsibility for bad fortune as well as the good. For both Lü and Guo, although karmic retribution is both the most powerful logic and a justification to record these stories at all, there are competing explanations for death and suffering: implacable fate (for Guo); ghosts seeking substitutes; and failure to take appropriate ritual action. But they are standing at very different positions: Guo as a male heir of a family legendary for multi-generational exam success that has maintained its status to some degree, Lü as a female heir of a male line that has died out. The Lü sisters' fame and prominence independent of male kin stands in contrast to traditional ideas of prosperity and continuity. Guo was able, despite historical change and disruption, to hang on to records of his patrimony. Lü was disinherited by the actions of her father's clan. Far more than for Guo, the stories are what she had. Guo was writing for his grandchildren and 
descendants, worrying about family tradition attenuating, but even in the more personal Suibi, it is unclear whether Lü was writing for her son.

Nevertheless, Guo recognized Lü as a kindred spirit preserving the memories of a literati clan and arguing for continuity of the principles of karmic retribution. Her gender was not of crucial concern in his citation of her stories. In one of his first references to stories from her collection, he said they came from “a contemporary person's miscellany 時人筆記” (Guo [1934] 2010, 2.33-34).

The gender of the compiler alone does not determine the gender structure of family recollection. Lü Meisun had clearly heard more stories from her mother than from her father, but her mother was not the same, hearing and retelling many stories from and about paternal relatives. Guo could entertain both a stricter definition of the family in Jiude shuwen and a more capacious one in Dongling xiaozhi.

On a spectrum from works devoted to one's own family to those placing familial experience in a larger context, of the works studied in this article, Guo's Jiude shuwen is the most exclusively focused on the family, and Lü's Yinweishi bilu is the most focused on didactic messages applicable beyond the familial context, with Dongling xiaozhi (as well as its sequels) and Mianliyuan suibi between the two extremes. This range illustrates the framing of family stories for personal and impersonal meaning. Nonetheless, relating a tale of loss as a warning for others still retains the function of trying to make sense of loss.

In the same decade when they compiled their tale collections, Lü and Guo both published works by members of their family: Guo by his great-grandfather, grandfather, father, and an uncle, Lü, as previously mentioned, by her father with a scant number of poems by her two deceased sisters appended (Guo et al. 1968; Lü Fengqi 1934). In one of his stories, Guo relates the tradition that humans have three souls and that, after death, one goes to the underworld, one stays by the grave, and one stays by the spirit tablet (Guo [1936] 2010, 2.203). The soul that enters the underworld enters larger systems of justice, and quite possibly goes on to other lives and other families. The other two are tied to physical places and objects that living family members must tend. To print either their works or works retelling their stories is to create additional sites for preserving relations with the souls of the departed family, all the more important when the graves are either lost or distant. The stories that convert familial experience into didactic lesson evoke the experience of the soul in the underworld, being judged before it moves on to other lives in other families.

Funding: This research received no external funding.

Conflicts of Interest: The author declares no conflict of interest.

\section{References}

Campany, Robert Ford. 1996. Strange Writing: Anomaly Accounts in Medieval China. Albany: State University of New York Press.

Dudbridge, Glen. 2002. Religious Experience and Lay Society in T'ang China: A Reading of Tai Fu's Kuang-yi Chi. Cambridge: Cambridge University Press.

Fong, Grace S. 2004. Alternative Modernities, or a Classical Woman of Modern China: The Challenging Trajectory of Lü Bicheng's (1883-1943) Life and Song Lyrics. Nan nü 6: 12-59. [CrossRef]

Gan, Bao 干寶, and Qian Tao 陶潛. 2004. Xin ji sou shen ji 新輯搜神記. Xin ji sou shen hou ji 新輯搜神後記. Edited by Jianguo Li 李劍國. Beijing: Zhonghua shuju.

Guo, Zeyun 郭則澐. 2010. Dongling xiaozhi xuzhi buzhi 洞靈小志續志補志. Beijing: Dongfang Chubanshe. First published 1934.

Guo, Zeyun 郭則澐. 2010. Dongling xiaozhi xuzhi buzhi 洞靈小志續志補志. Beijing: Dongfang Chubanshe. First published 1936.

Guo, Zeyun 郭則澐. 2010. Dongling xiaozhi xuzhi buzhi 洞靈小志續志補志. Beijing: Dongfang Chubanshe. Undated post-1936 manuscript first published 2010.

Guo, Zeyun. 1936. Jiude shuwen 舊德述聞. Tianjin. 
Guo, Boyin 郭伯蔭, Shichang Guo 郭式昌, Chuanchang Guo 郭傳昌, and Zengxin Guo 郭曾炘. 1968. Houguan Guoshi jiaji huikan侯官郭氏家集彙刊. In Jindai zhonguo shiliao congkan 近代中國史料叢刊. Edited by Zeyun Guo. Taipei: Wenhai Chubanshe, vol. 299, Originally published 1934.

Huntington, Rania. 2005. Chaos, Memory, and Genre: Anecdotal Recollections of the Taiping Rebellion. Chinese Literature: Essays, Articles, Reviews 27: 59-91.

Huntington, Rania. 2010. The View from the Tower of Crossing Sails: Ji Yun's Female Informants. Nan nü 12: 30-64. [CrossRef]

Ji, Yun 紀昀. 1994. Yuewei caotang biji 閲微草堂筆記. Shanghai: Shanghai guji.

Lü, Bicheng 呂碧城. 2017. Xiaozhu ci 曉珠詞. In 呂碧城著作集. Edited by Xian Hui 會閒, Jin Zhong 鍾錦 and Baomin Li 李保民. Beijing: Zhonghua shuju. First published 1937.

Lü, Meisun. 1930. Yinweishi bilu 寅畏室筆錄. Shanghai: Foxue shuju 佛學書局.

Lü, Meisun. 1931. Mianliyuan shi 葂麗園詩. Qingdao.

Lü, Meisun. 1933. Mianliyuan shixu菟麗園詩續. Qingdao.

Lü, Meisun. 1934. Mianliyuan shi zaixu菟麗園詩再續. Qingdao.

Lü, Meisun. 1941a. Mianliyuan suibi菟麗園隨筆. Qingdao.

Lü, Meisun. 1941b. “Qiansheng shi” 前生詩. Jue you qing 覺有情, February 16.

Lü, Fengqi 呂鳳岐. 1934. Jingran zhai zazhu 靜然齋雜著. Edited by Meisun Lü. Qingdao.

Meyer-Fong, Tobie. 2013. What Remains: Coming to Terms with Civil War in 19th Century China. Stanford: Stanford University Press.

Ning, Jiayu 寧稼雨. 1996. Zhongguo wenyan xiaoshuo zongmu tiyao 中國文言小説總目提要. Jinan: Qilu shushe.

Qin, Fang 秦方. 2010. Wanqing cainu de chengzhang licheng: Yi Anhui Jingde Lü shi zimei wei zhongxin 晚清才 女的成長歷程: 以安徽旌德呂氏為中心. Jindai zhongguo funü yanjiu 近代中國婦女研究 18: 259-94.

Qin, Fang, and Emily Bruce. 2018. The Education of European and Chinese Girls at Home in the Nineteenth Century. In A History of the Girl: Formation, Education, and Identity. Edited by Mary O'Dowd and June Purvis. Cham: Palgrave Macmillan, pp. 103-22.

Xu, Feng'en 許奉恩. 1996. Lanshaoguan waishi 蘭苕館外史. Hefei: Huangshan chubanshe.

Xu, Xinyun 徐新韻. 2015. Lü Bicheng san zimei wenxue yanjiu 呂碧城三姊妹文學研究5. Guangzhou: Jinan University Press.

Yu, Zhi 余治. 1873. Shujitang jinyue 庶幾堂今樂. Suzhou: Dejianzhai.

Yu, Yue 俞杫. 2010. Youtai xianguan biji 右台仙館筆記. In Chunzaitang quanshu. Nanjing: Fenghuang Chubanshe, vol. 5 .

Zhang, Zhenguo 張振國. 2011. Wanqing minguo zhiguai chuanqi xiaoshuo ji yanjiu 晚清民國志怪小説集研究. Nanjing: Fenghuang Chubanshe.

(C) 2019 by the author. Licensee MDPI, Basel, Switzerland. This article is an open access article distributed under the terms and conditions of the Creative Commons Attribution (CC BY) license (http://creativecommons.org/licenses/by/4.0/). 